\title{
Perfil Higiênico-Sanitário de Ricotas Frescas Comercializadas Na Cidade de João Pessoa, Paraíba, Brasil
}

Jossana Pereira de Sousa (II), Neusa Lygia Vilarim Pereira (I),

Edjeyse de Oliveira Cunha (I), Rhayane Idalyne Carvalho (I), Roberta Santos Lima (I), Eryka Maria Santos Alves (I), Evandro Leite de Souza (I), Maria Lúcia da Conceição (I)

(I) UFPB - Universidade Federal da Paraíba (Cidade Universitária - João Pessoa - PB - Brasil CEP: 58051-900), (II) UFPE - Universidade Federal de Pernambuco (Cidade Universitária -

Recife - PE - Brasil - CEP: 50670-901)

\section{Resumo}

Várias alternativas têm sido desenvolvidas visando à utilização sustentável do soro oriundo da fabricação de queijos, como por exemplo, a produção ricota, elaborada a partir do soro acidificado e tratado termicamente. Por ser um queijo fresco de alto teor de umidade, a ricota é bastante susceptível à proliferação de espécies microbianas, fato que motivou a realização desta pesquisa, que objetivou traçar o perfil higiênico sanitário de ricotas frescas comercializadas em João Pessoa, Paraíba. Foram coletadas dez amostras de queijo ricota tipo fresca, das quais, cinco (50\%) pertenciam à marca Ra, três $(30 \%)$ à marca Rb e duas (20\%) à marca Rc, e encaminhadas sobrefrigeração ao Laboratório de Microbiologia e Bioquímica de Alimentos/Departamento de Nutrição/CCS/UFPB para avaliação quanto à presença de Estafilococos coagulase positiva, pela técnica spread plate em Agar Vogel Johnson $\left(35 \pm 2^{\circ} \mathrm{C} / 48 \mathrm{~h}\right)$, contagem de bolores e leveduras por spread plate em Agar Sabouraud $\left(28 \pm 2^{\circ} \mathrm{C} / 3-5 \mathrm{~d}\right)$, coliformes totais por esgotamento em Agar Vermelho Violeta Bile $\left(35 \pm 2^{\circ} \mathrm{C} / 48 \mathrm{~h}\right)$ e coliformes termotolerantes em Caldo $\mathrm{EC}\left(45^{\circ} \mathrm{C} / 24 \mathrm{~h}\right)$, com posterior semeadura dos tubos positivos (presença de gás) em Agar Eosina Azul de Metileno $\left(35 \pm 2^{\circ} \mathrm{C} / 24 \mathrm{~h}\right)$ e confirmação das colônias características de Escherichia coli 
pelo teste INVIC. Estafilococos foram isolados em cinco (50\%) amostras, das quais duas (40\%) pertenciam à marca Ra, duas (40\%) à Rb e uma (20\%) à Rc, apresentando contagens no intervalo de 4,50 ( $\pm 0,50)$ a 6,17 $( \pm 0,02) \log _{10} \mathrm{UFC} / \mathrm{g}$, as quais se encontram acima do limite máximo permissível fixado pela legislação vigente $\left(5 \times 10^{2} \mathrm{UFC} / \mathrm{g}\right.$ ou $\left.2,7 \log \mathrm{UFC} / \mathrm{g}\right)$. Os bolores e leveduras foram detectados em oito (80\%) amostras, com populações variando entre $4,56( \pm 0,28)$ e $8,26( \pm 0,18) \log _{10} \mathrm{UFC} / \mathrm{g}$ e os coliformes totais em sete (70\%) amostras, apresentando contagens na faixa de $4,39( \pm 0,13)$ a $7,01( \pm 0,53) \log _{10} \mathrm{UFC} / \mathrm{g}$. Os coliformes termotolerantes foram isolados em três (30\%) amostras, com contagens variando no intervalo de 1,79 a $6,20 \log _{10} \mathrm{UFC} / \mathrm{g}$, embora não se tenha isolado Escherichia coli. Portanto, pode-se concluir que os percentuais de amostras contaminadas por Estafilococos coagulase positiva, bolores e leveduras e coliformes foram elevados, constituindo um indicador da qualidade higiênico-sanitária insatisfatória da ricota, fato que pode ser atribuído à manipulação imprópria do produto.

Palavras-Chave: Condição higiênico-sanitária, Indicadores de qualidade, Ricota fresca

\section{Agência de Fomento:}

